\title{
Grammatical Errors in Narrative Essay Writing by Students at Ganesha University of Education
}

\author{
Gde Arys Bayu Rewa ${ }^{1}$, Ketut Artawa ${ }^{2}$, Ni Ketut Widhiarcani Matradewi ${ }^{3}$ \\ ary sbayurewa77@gmail.com \\ Udayana University, Denpasar, Indonesia
}

\begin{abstract}
This study aims to find out the types of grammatical errors and analyze the grammatical errors committed by second semester students of English Language Education Study Program at Ganesha University of Education. This study is classified into qualitative research design. To analyze the data, theory types of errors proposed by Dulay et al. (1982) and sources of error from Richards (1974) were applied. The data were sentences on narrative essay writing containing errors taken from final assignments of the second semester students of the English Language Education Study Program at Ganesha University of Education. There are 86 data containing omission, 34 data containing addition, and 286 dat containing misformation. Meanwhile, the source of grammatical error that the researchers found are 6 errors caused by interlingual transfer and 22 caused by interlingual transfer.
\end{abstract}

Keywords: Grammatical Error, Narrative Essay Writing, Error Analysis

\section{Introduction}

Four skills in English have to be mastered by foreign leamers. There are listening, reading, speaking, and writing. From those skills, writing is the most difficult one for all language leamers, whether the language is the first, second, or foreign language. "Writing is difficult to learn because authors should utilize a proces s that includes planning, organizing, and revising to present meaning in word form" (Palmer, 1994:1). In line with Palmer, Richards and Renandya (2002: 303), stated that writing is the most difficult skill for second language learners to master. The skills involved in writing are highly complex.

Furthermore, Hamp-Lyons in Nunan (1991: 91) explains that it is true that writing is commonly a difficult activity for most people, both in their mother tongue and in a foreign language. The writing skill requires capabilities more than other language skills and needs special preparation. Writing is a complex process. There are several language aspects involved in writing, such as model texts, prepositions, spell-check, punctuation, and grammar.

English language leaming is a process where all English skills (listening, reading, writing, speaking, and grammar) are interconnected. In developing leamers writing proficiency, all language skills must be involved. Aiming at mastering those skills, students quickly learn when they feel confident expressing their ideas. They find English rules very complicated because some language features such as sentence construction, grammar, 
vocabulary, spelling, and so forth in their mother tongue are different from those of the target language. These make them difficult to express themselves in a clear, correct, and understandable manner of writing. Lado affirmed that "those language features that are similar to the (leamer's) native language will be simple for him, and those areas that are different will be difficult" (Lado in Richards, 1987: 46).

Grammar is one of the skills which is useful in process writing. But the problem is, many students still make some errors in writing and arranging some sentences to be a paragraph. Dulay in Brown (1994: 205) states that an error is a deviation from the adult grammar of a native speaker. Finding L2 learners' errors are evidence of learning because an error has played an important role in studying language acquisition.

The difficulties in applying the rules of the language in writing because students make errors. Dulay states that 'an error is a noticeable deviation from a native speaker's adult grammar' (Dulay in Brown, 1994: 205). It means that leamers make errors because they lack knowledge of the rules of the target language. They may make the same errors at other times. Error is often considered students' mistakes in learning a language because the comprehension of that ules is related to the student's ability. Selinker points out that when a student makes a mistake, it is not the teacher's fault or the materials or even the students, but it is a natural part of a leaming process (Selinker in Pranowo, 1996:50). People cannot leam a language without systematically committing errors first. Errors that learners make contribute to understanding the process of foreign language acquisition. By seeing students' errors, the researcher tries to collect information about students' errors in writing. Further analysis is needed to know in which langu age as pects they make errors and their frequency.

English Education students are prepared to be English teachers. They should have good competence in all language skills to be good Eng lish teachers. They should become not only good listeners and speakers but also good readers and writers. It is impossible to teach effectively if their English ability is poor. They will effectively teach writing if they master writing and other language skills. In attempting to master aspects of writing skills, it is necessary to analyze errors in written text to determine how much their acquisition is obtained in the teaching process.

Based on my pre-research, even though students have leamed grammar, most of them still faced some writing problems. Students have studied grammar rules but seldom put that knowledge to practical use (Wachs, 1993). Commonly it causes the target languages are different from their mother tongue. In second language acquisition, learners will be faced two systems that can probably influence each other (L1 $\leftrightarrow$ L2) (Kecskes \& Papp, 2000).

According to Ramelan (2003), the student's adversity in language acquisition is caused by the different elements found between the first language and target language. Lado affirmed that 'that language features that are similar to the (leamers) the native language will be simple for him, and those areas that are different will be difficult' (Lado in Richards, 1987: 46). An analys is is needed to know in what aspects they make errors most frequently by seeing this fact.

Taking into account the aforementioned points, it is important to understand the learners' problem in order to improve the quality of foreign language learners writing (Hammad, 2012). In this case, Error Analysis (EA) becomes as one of best tools of linguistic studies which concerned on learners' error. Error analys is in language teaching and leaming is as the technique of identifying, classifying and systematically interpreting the unacceptable forms produced by someone learning a language, especially a foreign language using any of the principles and procedures provided by linguists (Cry stal, 1999).

Despite of this fact, based on my own experienced and observation, I found that many students of English Language Education Department at Ganesha University of Education made some errors in their essay writing (narrative essay). They frequently make errors in terms of grammar such as subject-verb agreement, tenses when writing in English. They also committed common errors included misplacing some verbs, adverb, and so on. 
Most of students made these errors because they lack of knowledge about using past verb. The errors are made by students who rejected about the grammar less on in the class. Besides, the language feature of narrative text is using action verbs in past form. About narrative, Knapp and Watkins (2005) add that formally, narrative sequences people/characters in time and space.

There are several related previous studies which lied the research on narrative writing. HauTse (2014) investigated on grammatical errors made by Malaysian students. The study was reported that there were six significant errors that occurred in their writing such as singular/plural noun, article, preposition, adjective, subject-verb agreement, and tense.

Mohammed (2016) conducted a study to analyze grammatical errors in writing of Iraqi EFL learners. The findings of this study showed that the common errors of grammar in the subjects' writing include verb tense and form, subject- verb agreement, articles, preposition, misuse of pronoun, misuse of plurals, and misuse of auxiliaries. Moreover, another study was conducted by Jannah (2015) to analyze students' writing. She reported that most of mistakes made by students were: missing subject, missing be in simple predicate, wrong simple predicate missing be, superfluous be, mis information of passive form, the verb comes after the subject, pronoun form, agreement, and reference.

The above explanation and the previous studies lead the researcher to conduct this research to analyze students' writing especially in their grammatical errors. This research is hope to be of use for more effective teaching. Error analysis of the students' writing will make them aware errors when writing narrative text and this knowledge, according to Subramanian in Amiruddin (2018) cited in can help teachers identify specific language problem.

\section{Theoretical Framework}

Every study should be supported by significant theories, proposed by some experts in the field of English learning. The theory of error types in Surface Strategy Taxonomy proposed by Dulay et al. (1982: 154) in their book entitled Language Two is applied to identify types of grammatical errors in narrative essay writing. The theory from Richards (1974: 5) about the factors of errors in his book entitled Error Analysis: Perspective of Second Language Acquisition is used to analyze the sources of errors occurring from the leamers based on the second problem. This research is also supported by the theory of English grammar proposed by Parrott (2000: 93) in his book entitled Grammar for English Language Teachers, which describes about English grammar.

\subsection{Types ofErrors}

Regarding the theoretical framework to the study of error analysis, first of all, errors should be identified and then they should be described. A number of categories are suggested for the error analysis. The categories developed in analyzing error made by the students consist of several altematives for error classification. Dulay et al. (1982: 154-162) classify the types errors into four different categories. They are: (1) omissions, (2) addition, (3) misformation, and (4) misordering. These categories provide a great deal of potential in defining cognitive mechanisms behind the reconstruction of the new language. This also takes into account the errors are not a function of laziness or slowness, yet are based on certain logics due to interim concepts used in the development of a new language. Classifying errors using those categories is very useful as it can physically highlight the perceptual process that ensures the reconstruction of the learner of the mother tongue and the target language. 


\subsection{Sources ofError}

In order to analyze the error which is made by the leamer, it is important to make clear explanation about the error. In fact, errors are considered as the important mark of the language development in language learning. Richards (1974: 173) states that there are two sources of the leamer's errors. They are the errors caused by the learner's native language and the structure of the English itself. The causes of error are categorized into interlingual factors and intralingual developmental factors.

\subsection{Narrative text}

Narrative has social function to amuse, entertain and to deal with actual vicarious experience in different ways, narrative deal with problematic events which lead to a crisis or tuming point of some kind, which in tum finds a resolution (Dody, etc., 2008). Narratives are stories about person or a group of people overcoming problems (Joyce \&Feez, 2000). They also explain that narratives show how people react to experiences, explore social and cultural values and entertain the audience. Keraf (2001) defines several kinds of narrative: (1) Expository narrative usually tells about the factual events. It also tells about the steps of event to the readers. The pupose of this narrative is to explain the object of the story more details. (2) Suggestive narrative is difference from expository narrative because it emphasizes the suggestive sense. The purpose of this narrative is to give an explicit message and to increase the readers' imagination. (3) Fiction and nonfiction. Narrative fiction is called as traditional stories or folktales while non-fiction explains the event that has occurred in the past. Narrative fiction includes fairy tales, myths, legend, and fable. Narrative non-fiction includes anecdotes, autobiography, biography, and history.

Knapp (2005) adds there are three types of narrative text: (1) Personal narrative text. This narrative tells about the writers' personal story or experiences. This is known as personal narrative. (2) Imaginative narrative. The writers create a fiction story. The writers usually create unusual situations or event that could never happen in real life. (3) Narrative essay. Narrative essay is always written from a defined point of view. A narrative essay includes vivid verb and modifier, as well narrative essay is very precise in description of the character. This research would like to explore students' personal narrative in the form of narrative es say.

Anderson and Anderson (2003) state that narrative text usually includes the following grammatical features: (1) Nouns are to identify the specific characters and places in the story. (2) Adjectives are to provide accurate description of the characters and setting. (3) Time words are to connect events to tell when they occur. (4) Verbs are to show the actions that occur in the story. Meanwhile, this study suggested another classification of grammatical errors based on Betty S. Azar. Azar (1989) mentions that there are seven grammatical features in writing narrative text such as singular-plural, verb tense, word choice, word order, punctuation, capitalization, and spelling. Therefore, this research employs Azar's classification of grammatical errors to find out the common types of grammatical errors in students' writing narrative text.

\section{Res earch Method}

This study's design is qualitative using a descriptive approach since the res earcher' purposes are to analyze and describe the grammatical error found in students' essay writing at English Language Education Department students at Universitas Pendidikan Ganesha. Collecting, analyzing the data, understanding the data, and describing the result of the analysis are emphasized in this study because qualitative analyses provide detail, process, richness, and sensitivity to context and they are appropriate if the aim is to unders tand the meaning and to build theoretical explanations from participants understanding (Phyllis, 2007:17). 
A qualitative approach is one in which inquirer often makes knowledge claims based primarily on constructivist perspectives. The method used for the present study is the case study. Kalof et al. (2008: 152) state that a case study is an in-depth study of a single person, event, community, or group. In addition, Setiyadi (2006: 287) adds that a case study is a research method that describes a phenomenon clearly. It means to analyze the grammatical error in essay writing is needed the approach. The researcher chooses this approach because the writer wants to know deeper what kinds of grammatical errors.

The setting of this study will be conducted at Ganesha University of Education. This university is located in Jalan Udayana, Singaraja. However, during the covid-19 pandemic, the teaching and learning process is conducted from home. Remote leaming is held through online applications, such as WhatsApp Group, Google Classroom, and Zoom. Furthermore, the researcher will conduct this present research through those applications as well.

This research is conducted from the beginning of January 2021. With the enactment of WFH (Work from Home) therefore, this research will be online. This study began by conducting preliminary research to determine student problems. Afterward, proceed to look at the students ' writing and see grammatical errors. Furthermore, the researcher will research how the data collection process proceeds by analyzing the data listed in the research model when data collection has been completed.

In this study, the research subjects are the English Language Education Department students in the academic year 2020/2021. All these students are in writing class and were now in the first year of a four-year program in teacher training, preparing to be teachers of English as a foreign language. They were all native speakers of Indonesian. This sample was selected without the barriers of gender and religion. The researcher preconceived the subjects to have been shared similar English proficiency levels and hence homogeneous. Thus, the sample formed a group quite representative of young educated students.

Document study is a method of collecting data by collecting towards documents. The documents collected are selected according to the purpose and focus of the problem (Sukmadinata, 2016: 221-222). To collect the data needed in this study, narrative texts made by students were collected to be analyzed in terms of the grammatical errors on narrative essay. The narrative essay writings are taken from the students' final assignment. The choice of the topic is a suggestion from the English lecture and is adjusted to the theme being taught.

After the narrative essays writing are collected and thoroughly examined and identified, the data that is the focus of the study are then grouped according to the types of grammatical errors that may arise. Before a more in-depth analysis was conducted, interviews were held with students, especially for essays that had a lot of errors or lack of standard in the use of English verbs. The purpose of this interview is to find real reasons why non-standard English is still used. The results of the interview can be used to ans wers the source of errors committed by the students.

The technique of collecting data in this study is observation technique by observing in the students' writing. Moreover, note taking used while observing the errors and it was done by several steps. The first step was reading the essay writing comprehensively. After that, words, phrases and sentences containing grammatical error are highlighted. The next step was taking note the classification of types of grammatical error according to the Surface Strategy Taxonomy from Dulay et al. (1982), which then the data are corrected by using a book reference on the rules of English grammar from Parrott (2000).

The study which focusses on the data of English ess ay writing made by English Education Study Program students had been analyzed in order to find out the grammatical error on narrative essay writing as well as the how the error committed by the students. Therefore, the theory of Error Analysis procedures from Gass and Selinker's (2008: 103) was applied to analyze the data gained. There are several steps of error analysis provided by Gas and Selinker, namely: (1) Identify errors. Identifying the types of errors made e.g.: omission, addition, misformation, or misordering using theory proposed by Dulay et al. (1982). (2) Classify errors. 
Grouping the errors that have been found and stating the classes of the errors e.g.: errorof verb tense, error of auxiliary verb, etc.(3) Analyze error. This step dealt with deeper analysis of the errors found and the sources of errors in the students' writing using the theory proposed by Richards (1974). The source of errors analyzed through relating the error with the theory about the sources of errors and confirmed by the result of the notes taking from the interview.

The presentation of the data analysis of this study took formal and informal methods. There are two ways of presenting data analys is, both formal and informal, according to Sudaryanto (2015: 145). The formal method uses numbers, statistics, tables, graphics, and so on to present data analysis, whereas the informal method uses detailed descriptions.

The data result of the study is presented using the formal method, the form of tables is used with columns for each type of errors found as well as the result of the sources of the errors. The data of the total types of errors and sources of errors found are also tabulated in numbers in order to find out the percentage of each type and the source of errors. Moreover, this study is also used informal method of presenting analysis by explaining the data descriptively using words and sentences, since this stu dy is qualitative research approach.

\section{Discussion}

\subsection{Types ofError}

The total grammatical errors in 2A students' narrative essay writing are 386 errors. The errors found are:

1. Omis sion error divided into: omission of main verbs: 65 , omission of auxiliary verb: 10 , Omission of article: 3 , omis sion of noun: 3 , Omis sion of conjunction: 2 , Omission of subject: 3 .

2. Addition Error divided into: simple addition of verb: 11, simple addition of au xiliary verb: 10 , simple addition of quantifier: 2 , simple addition of noun: 8 , simple addition of article: 1 , and double markings addition: 2 .

3. Misformation error divided into: Misformation altemating form of verb: 100, Misformation altemating form of auxiliary verb: 139, Misformation alternating form of modal: 40, Misformation altemating form of article: 3 , Misformation alternating form of noun: 2, Misformation altemating formof adjective: 1, Mis formation achi-form of pos sessive: 1 .

\section{A. Omission}

\section{(S 24) Ioften visit there about 2 weeks for check-ups}

The sentences above are examples of grammatical error because in delivering a past event or narrative text, the verb should be written in simple past form. The verbs on those sentences are regular verbs, thus should be added d/ed to make it into simple past form and represent a past event. Therefore the correction of the verb in the sentence above can be corrected into: "I often visit there about 2 weeks for check-up" which omitted the "ed" of the verb "visit". The simple past tense sentence needs simple past formed verb to build the sentence. Without the simple past formed verb, it either becomes an other form of tenses or ambiguous because it can change the meaning. Thus, the verb "visit" needs suffix "ed" to make it into simple past form. The correct sentence is "Ioften visited there about 2 weeks for check-up".

\section{B. Addition}

(S-6) When sad scenes they are cried

"Are" in that sentence is an item that must not appears because "cried" is a simple past form of "cry" infinitive. It shows a double marking where the sentence has 2 predicate with "are" as the auxiliary verb and "cried" as the verb. The correction form of this sentence is "When sad scenes, they cried". 


\section{Misformation}

(S-1) I was driving it to went to school

The sentence above has "to" followed by simple past verb which shows a misformation of verb in a simple past sentence. Any verb following "to" should be written in form of infinitive verb. Thus, the correct sentence is "I was driving it to go to school".

\subsection{Grammatical Error}

According to Error Analys is theory from Richards, there are two sources of errors that involved in students' errors in the use of verb: interlingual error and intralingual error. Richards (1974: 94) stated errors due to rules from mother tongue are called interlingual error. It is because the different system between Indonesian and English. Intralingual transfer is produced by learners which do not reflect the structure of the mother tongue, as well as generalization based on limited exposure to the target language (Richards, 1974: 174). It was found that 27 students made 22 of intralingual errors in total. It means that the students were failed to leam conditions under which rules apply. There were 8 intralingual error of overgeneralization, 5 intralingual errors of ignorance of rules restriction, 4 intralingual errors of incomplete application of rules, and 5 intralingual error of fals e concept of hypothesis.

\section{A. Interlingual Error}

(S 18) which we know is that the danceis wearing clothes that look like kemben

Translation in Bahasa Indonesia: Yang kita ketahui adalah tarian yang mengenakan kain semacam kemben. This sentence is affected by L1 which makes the sentence sounds a lot more complicated than it should. The student wants to explain about Tari Tenun she performed when she was a child. That dance wears a peace of clothe named Kemben to cover the upper part of dancers' body. Thus, the correct sentence is "which is danced by wearing clothe that look like kemben".

B. IntralingualError

(S 13) I had surgery

It should be: "I had a surgery". This sentence needs an article before the noun, but the writer failed to apply the rules by making this sentence.

Overgeneralization

(S 11) The first thing that me and my friends did is put up the tent and prepa red the tools for cooking

It should be: "The first thing that my friends and I did was putting up the tent and prepared the tools for cooking". The writer extended the use of grammatical rules by using "is" as be but followed by infinitive. It should be "is" or"was" followed by progressive verb.

Ignorance ofrules restriction

(S 3) but she always saying that I will ma ke it

It should be "but she always said that I will make it". In writing a narrative text, the tense that is usually us ed is simple past tense because the text tells about an experience or event happened in the past. But here the 
writer wrote the word "saying" without putting any to be before the verb or forming the verb into simple past form.

$$
\text { Incomplete application ofrules }
$$

(S 3) I stand up

It should be: "I was standing up". The action of standing up takes time and can be followed by other actions. On the text, the writer wrote other actions such as; freaking out, walking up and down, and biting nails which are categorized as procedural actions.

False Concept of Hypothesis

(S 26) I used to be a woman who was getting used to living a lone

It should be: "I used to be a woman who was getting used to live alone". The verb should be infinite when there is "to" in front of it. Thus, the writer should write "....to live..." instead of"...to living..."

\section{Conclusion}

This study investigated the types of grammatical errors on narrative essay writing made by the $2 \mathrm{~A}$ class of English Language Education Study Programstudents at Uniersitas Pendidikan Ganesha. The data showed that the types of errors found were: (1) Omission error divided into: omission of main verbs: 65, omission of auxiliary verb: 10 , Omis sion of article: 3 , omission of noun: 3 , Omission of conjunction: 2 , Omission of subject. (2) Addition Error divided into: simple addition of verb: 11, simple addition of auxiliary verb: 10, simple addition of quantifier: 2 , simple addition of noun: 8 , simple addition of article: 1 , and double markings addition: 2. (3) Misformation error divided into: Misformation alternating form of verb: 100, Misformation altemating form of auxiliary verb: 139, Misformation alternating form of modal: 40, Misformation alternating form of article: 3, Misformation altemating form of noun: 2, Mis formation altemating formof adjective: 1, Mis formation achi-formof pos sessive:1.

The data from the interview with the students who committed error showed that interlingual and intralingual error were the factors causing grammatical error on the narrative essay writing. The interference of Indonesian grammar and direct translate from students' L1 when making English sentence was the cause indicate interlingual error. Furthermore, it was also found that the errors made by students was influence of lack knowledge from the target language which is called as intralingual error. This indicated that those students were failed to learn conditions under which rules apply for the correct English grammar.

\section{References}

Amiruddin.(2018). An Investigation of Errors in the Oral Performance among English Department Students (A Study at the Third Year Students of UIN Ar-raniry Banda Aceh). Banda Aceh: Unsyiah.

Anderson, M. \& Anderson, K. (2003).Text Types in English 2. Australia: Macmillan Education Australia PTY LTD.

Azar, B. S. (1989). Understanding and using English Grammar (2nd ed.). Englewood Cliffs, New Jersey: Prentice-Hall, Inc.

Brown, H. Douglas. (1994). Principles of Language Learning and Teaching. 3rd edition. Englewood Cliffs, New Jersey: Prentice Hall Inc Crystal, D. (1999). The penguin dictionary of language (2nd ed.). Penguin.

Dody, A., Sugeng, A., \& Effendi. (2008). Developing English Competencies: for Senior High S chool Grade X (1st ed.). Jakarta: Pusat Perbukuan, Departemen Pendidikan Nasional.

Dulay, H., Burt, M., Krashen S. (1982). Language Two. Oxford: Oxford University, Inc.

Gass M. \& Selinker L. (2008). Second language Acquisition. An Introductory Course. 
Hammad, A. E. (2012). Teaching and learning English reading in Gaza prep schools: A New Descriptive study. A PhD dissertation, Cairo University, Egypt.

HauTse, A. Y. (2014). A Case Study of Grammatical Errors Made by Malaysian Students. International Journal of Science Commerce and Humanities, 2(5).UniversitiTuanku Abdul Rahman Faculty of Arts \& Social Science. Perak Campus 31900 Kampar: Malaysia.

Jannah, M. (2015). Analysing the Students' grammatical Error on Writing Narrative Text. Lampung: ST KIP Muhammadiyah P ringsewu. Joyce, H., \&Feez, S. (2000). Writing skills: Narrative and non-fiction text types. Sydney: Phoenix Education Pty Ltd.

Kalof, Linda., Dan, Amy and Dietz, Thomas. (2008). Essentials of Social Research, Open University Press: USA

Kecskes, I. and Papp, T. (2000) Foreign Language and Mother Tongue. Mahwah, NJ: Erlbaum.

Keraf, G. (2001). Argumentasi dan Narasi. Jakarta: Gramedia.

Knapp, P \& Watkins, M. (2005).Genre, Text, Grammar: Technologies for Teaching and Assessing Writing. Australia: UNSW Press.

Mohammed, M. Q. (2016). Error Analysis: A Study on Grammatical Errors in the Writing of Iraqi EFL Learners. European Academic Research, 3, ISSN 2286-4822.

Nunan, D. 1991. Language Teaching Methodology. New York: Prentice Hall.

Palmer, C. Barbara., Hafiner, L. Mary., and Sharp, F. Marylin. 1994. Developing Cultural Literacy Through the Writing Process. Massachusetts: Allyn and Bacon.

Parrott, M. (2000). Grammar for English Language Teacher. Cambridge: Cambridge University Press.

Phyllis, Tharenou. (2007). Management Research Method. New York: Cambridge University Press.

Pranowo. 1996. Analisis Pengajaran Bahasa. Yogyakarta: Gajah Mada University Press.

Ramelan. (2003). English Phonetics. Semarang: uness pressing.

Richards, I.A. (1974). Techniques in Language Control. Rowley: Newbury House Publishers.

Richards, C. (1987). The Context of Language Teaching. Cambridge: Cambridge University Press. edition. Englewood Cliffs, New Jersey: Prentice Hall Inc

Richards, J. C and Renandya, W.A. (2002). Methodology of Language Teaching: an Anthology of Current Practice. England: Cambridge University Press.

Setiyadi, A. B. (2006). Metode Penelitian untuk Pengajaran Bahas a Asing Pendekatan Kuantitatif dan Kualitatif. Yogyakarta: Graha Ilmu. Sudaryanto. 2015. Metode Linguistik. Yogyakarta: Gadjah Mada University Press.

Sukmadinata, N. S. (2016). Metode Penelitian Pendidikan. Bandung: Remaja Rosdakarya.

Wachs, S. (1993). Breaking the writing barrier: Approaches to the composition class. In P. 